\title{
КОНТЕКСТНЕ НАВЧАННЯ У ФОРМУВАННІ ПРЕДМЕТНОЇ КОМПЕТЕНТНОСТІ НА ЗАНЯТТЯХ 3 БІОНЕОРГАНІЧНОЇ ХІМІЇ
}

Клименко С. О. Контекстне навчання у формуванні предметної компетентності на заняттях з біонеорганічної хімії.

У статті розглядаються особливості впровадження контекстного навчання на заняттях з біонеорганічної хімії в медичних коледжах задля формування предметної компетентності студентів. Охарактеризовано оцінку конструювання навчального процесу через діяльність. Запропоновано активні методи та форми організації навчальної діяльності, що сприяють реалізації контекстного навчання.

Ключові слова: компетенції, предметна компетентність, контекст, контекстне навчання, активні методи навчання.

Клименко С. А. Контекстное обучение в формировании предметной компетентности на занятиях по бионеорганической химии.

В статье рассматриваются особенности внедрения контекстного обучения на занятиях по бионеорганической химии в медицинских колледжах с целью формирования предметной компетентности студентов. Дана характеристика оценке конструирования учебного процесса через деятельность. Предложены активные методы и формы организации учебной деятельности, которые способствуют реализации контекстного обучения.

Ключевые слова: компетенции, предметная компетентность, контекст, контекстное обучение, активные методы обучения.

Klimenko S. A. Context-based learning in the formation of subject competence at the bioinorganic chemistry lessons.

The article covers peculiarities of using context-based learning with the purpose of providing professional orientation in teaching bioinorganic chemistry and the formation of subject competence. The characteristic to the construction evaluation of learning process through the activities is given. The active methods and forms of organization of learning activities that promote the implementation of contextual learning were proposed.

Key words: competence, subject competence, context, contextual learning, innovative teaching methods.

Нині суттєву кількість суб’єктів освітньої системи України не задовольняє іiі поточний стан і рівень розвитку. Водночас прагнення до змін шляхом піднесення ролі засобів комунікації та інформаційних технологій у розвитку суспільства сприяє поступовому оновленню освітньої галузі, суттєвому корегуванню. Також при цьому мають місце впровадження новацій у стилі діяльності педагогів та функціонуванні педагогічних систем на інноваційних засадах.

Якість освіти наразі не визначається лише кількістю позитивних оцінок. Із точки зору інноваційної педагогіки, новою якістю освіти стає ступінь розвиненості особистості людини, яка навчається; іiі підготовленості до продовження навчання [3]. Відповідно до оновлених освітніх стандартів підготовка спеціалістів будь-якого напрямку не залежить виключно від системи знань і вмінь. Суттєвих ознак якості освіти набувають додаткові властивості, для означення яких використовуються такі поняття, як «компетентність» та «компетенції». Саме тому 
на сучасному етапі розвитку освітньої системи України досить важливо впроваджувати найбільш активні, продуктивні й ефективні методи викладання, які сприяють розвитку предметної компетентності майбутніх фахівців. У свою чергу, саме високий рівень предметної компетентності допомагає формуванню професійної компетентності загалом.

Проблематика формування компетенцій у системі вищої освіти, зокрема медичної, привертала увагу багатьох дидактів і методистів. Вивченню окресленої проблеми присвячені дослідження С. Бухальської (компетентнісний підхід у вищій медичній освіті), Р. Іваненко (професійна компетентність медика), Г. Кліща (професійна компетентність медичного спеціаліста), В. Копетчук (професійна спрямованість у підготовці медичних спеціалістів), Т. Літвинової (роль хімічної підготовки у формуванні ключових компетентностей), М. Лукащука (навчальна компетентність студента-медика), К. Люшук (інноваційні технології в медичних навчальних закладах), І. Радзієвської (формування професійної компетентності у медичних сестер), В. Сліпчук (професійне спрямування хімічної освіти), Н. Стучинської (особливості організації самостійної роботи студентів ВМНЗ), Ю. Ткаченко (дидактичні засади формування професійних компетенцій) тощо. Вітчизняними й закордонними дослідниками напрацьована значна кількість матеріалу щодо методів і форм удосконалення навчально-виховного процесу, спрямованого на формування компетенцій студентів. Проте питання формування предметної компетентності з біонеорганічної хімії у студентів медичних ВНЗ III p. а. залишається недостатньо дослідженим.

У результаті здійсненого аналізу наукових напрацювань, із урахуванням власного педагогічного досвіду викладання біонеорганічної хімії в медичному коледжі пропонуємо організовувати навчально-виховний процес на засадах компетентнісного навчання. При цьому одним із шляхів його реалізації у процесі викладання біонеорганічної хімії у студентів-медиків уважаємо впровадження контекстного навчання.

Метою статті є визначення особливостей реалізації контекстного навчання в умовах викладання біонеорганічної хімії у вищих медичних навчальних закладах III рівнів акредитації.

Результати проведеного педагогічного експерименту дозволяють зробити висновок, що формування предметної компетентності студентів під час вивчення біонеорганічної хімії на більш високому рівні забезпечується за умови представлення процесу навчання не як традиційного передавання знань від викладача до студента, а як простору, у якому суб'єкти навчальної діяльності активно діють у контексті майбутньої професії. Досвід засвідчує, що створення такого «простору» в навчальному процесі забезпечується через упровадження контекстного (або знаково-контекстного) навчання, концепція якого була запропонована А. Вербицьким.

Відповідно до принципів знаково-контекстного навчання для досягнення мети формування особистості фахівця навчальний процес необхідно організовувати таким чином, щоб «забезпечити перехід одного типу діяльності (пізнавального) в інший (професійний) відповідною зміною потреб і мотивів, цілей, дій (вчинків), засобів, предметів та результатів» [1]. Умови такої трансформації забезпечуються зміною видів пізнавальної діяльності студентів: від власне навчальної (наприклад, на лекціях) через квазіпрофесійну (наприклад, створення ситуаційних задач, імітація професійних задач) i навчально-професійну (наприклад, організація дослідницької роботи студентів над проектами) до професійної діяльності. Інакше 
кажучи, сутність знаково-контекстного навчання зосереджується на відтворенні у формах i методах навчальної діяльності студентів реальних певних зв'язків i відношень, які передбачають максимальне наближення процесу засвоєння знань до реалій майбутньої професійної діяльності студента.

Ураховуючи вище зазначене, а також сучасний досвід упровадження контекстного навчання у вищій школі (Е. Андреєвої, Н. Бакшаєвої, О. Григоренко, В. Крутикової, В. Круглікова, О. Картьожнікової, О. Ларіонової, М. Мащенко, М. Тиріної, І. Тиханки, Ж. Холодова та ін.) доходимо висновку, що сутність його полягає в наближенні процесу навчання до майбутньої професійної діяльності медичних спеціалістів або їі фрагментів.

До основних принципів контекстного навчання науковці відносять: педагогічне забезпечення особистісного залучення студента до навчальної діяльності; послідовне моделювання цілісного змісту, форм і умов професійної діяльності фахівців; проблемність змісту навчання і процесу його розгортання; адекватність форм організації навчальної діяльності студента цілям і змісту освіти; провідну роль спільної діяльності, міжособистісної взаємодії й діалогічного спілкування суб'єктів навчального процесу; педагогічно обгрунтоване поєднання нових i традиційних педагогічних технологій; єдність навчання i виховання особистості професіонала [2].

Нині актуальною є проблема забезпечення якості підготовки фахівців ВН3 різних профілів. Набуває значущості питання формування компетентностей фахівця, як ключових, так і предметних. Науковцями доведено, що побудоване на основі діяльнісної моделі фахівця контекстне навчання забезпечує успішне формування професійних та особистісних якостей студентів.

Тому, моделюючи професійний зміст навчання майбутньої діяльності молодших медичних спеціалістів на заняттях із біонеорганічної хімії, основною метою вбачаємо розвиток у студентів предметних компетенцій. Від рівня їхнього розвитку залежить формування загалом здатності майбутнього медичного працівника аналізувати, прогнозувати i проектувати траєкторії власного професійного зростання.

Реалізовуючи один із принципів контекстного навчання - наближення процесу навчання до реалій майбутньої професійної діяльності або іiї фрагментів, намагаємось максимально запровадити його через проблемність змісту курсу i процесу його розгортання. Це передбачає розроблення лекційного матеріалу, завдань для практичної й самостійної роботи, навчальних проектів проблемного характеру. При цьому викладач одночасно виконує генеруючі функції у створенні нестандартних ситуацій i здійснює роль консультанта й експерта у процесі їх розв' язання.

Під час викладання лекційного курсу відбувається власне навчальна діяльність студентів. Завдяки організації та проведенню проблемних лекцій на заняттях 3 біонеорганічної хімії підвищується роль діалогічної взаємодії, забезпечується перехід від простого передавання змісту навчальної інформації до активного іiі засвоєння; формується підгрунтя задля подальшого сприйняття та усвідомлення студентами абстрактного навчального матеріалу. Наприклад, знання теоретичного характеру про розчини, розчинник, розчинювальну речовину, масову частку розчиненої речовини, умови розчинення речовин і способи приготування розчинів знаходять своє відображення під час розв'язання навчальних задач $з$ фармакології та ряду клінічних дисциплін. Методики розрахунків і приготування медичних препаратів - розчинів розглядаються в курсі «Сестринська справа». Отже, на лекції 
3 окресленої теми можна поставити загальну проблему вивчення розчинів в галузі медичної діяльності. Система проблемних завдань повинна охоплювати основні типи питань, що властиві відповідній галузі знань, а саме: утворення розчинів (на прикладі основних біологічних систем - плазма, кров, лімфа, сеча), розбавлення розчинних систем (способи вираження концентрації), наслідки неправильного розчинення чи розведення лікарських засобів тощо. При цьому викладач орієнтує студентів на розв'язання вказаних питань, наведених у чинних підручниках та наукових посібниках, обгрунтовує існуючи підходи й мотивує знаходження найбільш ефективних шляхів розв'язку.

Наступним етапом контекстного навчання $\epsilon$ самостійне опрацювання студентами отриманого навчального матеріалу, проведення порівняльних характеристик наявних методів вирішення задач, визначення й обрання найбільш ефективних шляхів розв'язку проблеми через розв'язання конкретних завдань i виконання вправ. Засвоєння знань на певному кроці набуває особистісного сенсу для студентів із перспективою їх застосування в майбутній професійній діяльності.

Практичний досвід засвідчує, що імітація тактики поведінки майбутнього фахівця медичної галузі на заняттях також досягається за допомогою системи проблемних задач і вправ, у яких моделюються реалії професійної діяльності. При цьому наповнення навчального матеріалу відбувається суто професійно спрямованою інформацією. Завдяки цьому розширюється фаховий досвід, відтворюється модель виробничих взаємовідносин, академічний процес наповнюється елементами особистісного значення знань. У підсумку все це сприяє переходу діяльності від навчально-пізнавальної до практичної.

Так, за використання задач-вправ моделюються прості професійні ситуації, аналіз та розв'язання яких сприяє більш повному усвідомленню та засвоєнню предметного змісту дисципліни. Наведемо приклад.

Задача 1. Калій - основний внутрішньоклітинний йон, що відіграє важливу роль у регулюванні функцій організму. Чи забезпечить добову потребу організму в Калії (3 г/добу) призначення внутрішньом'язово 20 мл 4\% розчину калій хлориду за умови його повного засвоєння?

Задача 2. Для проведення загальної анестезії під час операцій застосовують розчини хлороформу $\mathrm{CHCl}_{3}$. Обчисліть масову частку хлороформу в розчині, що утворений шляхом розчинення хлороформу об'ємом 5л у воді масою 300г.

Задачі-проблеми дозволяють моделювати складні, багатофакторні ситуації, пов'язані з організацією предметного змісту майбутньої професійної діяльності. Задачі цього типу можуть містити додаткові дані, інформацію для знаходження кількох шляхів вирішення. Наприклад:

Задача 1. У лабораторії було розбито термометр, і ртуть розлилась по підлозі. Ïї зібрали в посудину, яку закупорили. Лаборанту негайно необхідно провести демеркуризацію приміщення підкисленим хлоридною кислотою розчином марганцівки 3 масовою часткою калій перманганату $\mathrm{KMnO}_{4} 10 \%$. Запропонуйте швидкий грубий спосіб приготування розчину в однолітровій склянці. Яким способом можна приготувати такий розчин з точною концентрацією?

Задача 2. Задля проведення рентгенографічного дослідження захворювань травного тракту пацієнтові Д. призначили внутрішньо барієву кашу (основна речовина барію сульфат $\mathrm{BaSO}_{4}$ ). Але пацієнт Д. знає, що солі барію - це токсичні сполуки. Як пояснити пацієнтові, що в цьому випадку суспензія барійвмісної сполуки не володіє отруйними властивостями? 
Досвід доводить, що впровадження системи пізнавальних задач і вправ на практичних заняттях 3 біонеорганічної хімії, а також у процесі організації самостійної роботи дозволяє студентам відчути себе в ролі майбутніх фахівців. Відтворюючи контекст професійної діяльності в предметному й соціальному аспектах, ситуаційні завдання надають студенту змогу систематизувати й інтегрувати абстрактні знання і трансформувати їх у професійні.

Організація практичних занять у процесі реалізації контекстного навчання передбачає активне спілкування і взаємодію всіх учасників навчального процесу. При цьому головне призначення спільної діяльності, міжособистісної взаємодії і діалогічного спілкування суб'єктів навчального процесу реалізується через навчання в дискусії, спільне розв'язання ситуаційних завдань, рольові й імітаційні ігри тощо. Наприклад, на занятті «Кислотно-основна рівновага. Водневий показник у біосистемах» студентам пропонується порівняти кислотність біологічних рідин організму людини за шкалою рН. При цьому необхідно вміти пояснити чинники, які сприяють зміщенню кислотної рівноваги в організмі людини, та ті, які допомагають підтримувати сталість рН. Ця робота дозволяє студентам особисто переносити знання на процеси, що протікають в організмі та давати власну оцінку.

Досвід проведення практичних занять з біонеорганічної хімії показує, що в реалізації навчання контекстного типу найбільш продуктивною стає організація роботи студентів у малих групах. Така форма роботи сприяє результативній діяльності, забезпечує високий ступінь активності студентів, допомагає розподілу обов'язків і функцій у процесі розв'язання ситуаційних завдань й уможливлює виникнення колективного розв'язання професійної проблеми.

Звернемо увагу на те, що заняття повинні мати практико-орієнтований характер. У такий спосіб студентам надається змога побувати в ролі фахівця, моделюючи виробничі фрагменти; здійснити аналіз конкретних ситуаційних задач; надати їм оцінку з різних позицій - спеціаліста та пацієнта. При цьому основним видом діяльності $є$ квазіпрофесійна, що передбачає імітацію в аудиторії умов і динаміки реального фрагменту професійного майбутнього медичного спеціаліста середньої ланки. На нашу думку, саме під час квазіпрофесійної діяльності в умовах змодельованої професійної ситуації, предметні компетенції набувають найвищого свого розвитку.

Окрім запропонованих вище форм навчання, однією із продуктивних технологій, що дозволяють реалізувати принципи контекстного навчання на заняттях із біонеорганічної хімії, пропонуємо проектну. Вибір тем задля створення навчальних проектів 3 біонеорганічної хімії заснований на принципі доповнюваності і професійної спрямованості хімічної освіти в медичному ВНЗ. Наприклад, теми «Хімічний склад живих організмів», «Роль біогенних елементів у розвитку ендемічних захворювань», «Комплексні сполуки та метало-лігандний гомеостаз», «Застосування розчинів в медичній практиці», «Очищення організму електролітами» тощо сприяють реалізації як міжпредметної й міждисциплінарної інтеграції. Можливість моделювання поведінки медика, яка відтворюється у проектному продукті, забезпечує рівень належної мотивації до здобуття професійної освіти шляхом особистого залучення до процесів пізнання [2].

У світлі реалізації контекстного навчання важливою умовою, що передбачає формування предметної компетентності, є рефлексація. Традиційна педагогіка не передбачає аналізу набуття студентами предметної компетентності. Але в умовах упровадження зазначеного виду навчання, фіксування студентами стану свого розвитку, саморозвитку й аналізу їх причин стає необхідним методом оцінки якості 
процесу підготовки загалом. Найбільш ефективними в контексті досліджуваної проблеми обрано такі комплекси рефлексивних вправ, як «Телефон довіри», «Плюс-Мінус», «Завершення речення», «Готель», «Аркуш, який гуляє колом», що пропонуються в сучасній науково-методичній літературі [4].

Підсумовуючи викладене вище, зазначимо, що впровадження контекстного навчання на заняттях із біонеорганічної хімії в медичному коледжі передбачає:

- наближення процесу навчання до майбутньої професійної діяльності медичних спеціалістів або ії фрагментів шляхом використання системи проблемних задач та вправ;

- застосування проблемних методів навчання, у яких моделюються реалії професійної діяльності;

- реалізацію інтерактивних методів навчання шляхом спілкування і взаємодії всіх учасників навчального процесу;

- застосування проектних технологій навчання, результатом яких $\epsilon$ висвітлення шляхів розв'язання навчальних задач у контексті майбутньої професійної діяльності;

- узагальнення власних навчальних досягнень й аналіз власних дій, зокрема пізнання самого себе, шляхом рефлексивних дій та вправ.

Ураховуючи визначені особливості, уважаємо, що реалізація положень контекстного навчання на заняттях із біонеорганічної хімії є ефективною і сприяє формуванню предметної компетентності на більш високому рівні.

\section{Література}

1.Вербицкий А. А. Контекстное обучение: формирование мотивации / А. А. Вербицкий // Высшее образование в России. - 1998. - № 1. - С. 101-107. 2. Воробйова Т. В. Щодо реалізації положень контекстного навчання у процесі фахової підготовки майбутніх медиків [Електронний ресурс] / Т. В. Воробйова. Режим доступу: http://archive.nbuv.gov.ua/portal/Soc_Gum/Pfto/2011_19/files/ P1911.pdf. 3. Дичківська I. М. Інноваційні педагогічні технології : [підручник] / I. М. Дичківська. - $\quad$ [2-ге $\quad$ вид., $\quad$ доп.]. - $\quad$ К. : Академвидав, 2012. - 349 с. 4. Наволокова Н. П. Енциклопедія педагогічних технологій та інновацій / Н. П. Новолокова. - Х. : Основа, 2009. - 176 с. 5. Пометун О. І. Сучасний урок. Інтерактивні технології навчання : [наук.-метод. посіб.] / О. І. Пометун, Л. В. Пироженко. - К. : А.С.К., 2004. - 192 с.

\section{ХМАРО ОРІСНТОВАНЕ НАВЧАЛЬНЕ СЕРЕДОВИЩЕ, ВІРТУАЛІЗАЦІЯ, МОБІЛЬНІСТЬ - ОСНОВНІ НАПРЯМКИ РОЗВИТКУ ЗАГАЛЬНОЇ СЕРЕДНЬОЇ ОСВІТИ ХХІ СТОЛІТТЯ}

Литвинова С.Г. Хмаро орієнтоване навчальне середовище, віртуалізація, мобільність - основні напрямки розвитку загальної середньої освіти ХХІ століття.

У статті на основі узагальнення наукових результатів і дослідження стану впровадження інформаційно-комунікаційних технологій у навчально-виховний процес уточнено напрямки стратегічного розвитку загальної середньої освіти у XXI столітті.

Ключові слова: хмаро орієнтоване навчальні середовище, віртуалізація, мобільність, середня освіта, 3К-технології. 